\title{
ASSOCIATIONS BETWEEN ATTRIBUTES OF NITISOLS AND THE CLIMATE OF THE SOUTHERN COAST OF PERNAMBUCO ${ }^{1}$
}

\author{
LAÉRCIO VIEIRA DE MELO WANDERLEY NEVES ${ }^{2}$, JEAN CHEYSON BARROS DOS SANTOS ${ }^{2}$, VALDOMIRO \\ SEVERINO DE SOUZA JÚNIOR ${ }^{2 *}$, MARCELO METRI CORRÊA ${ }^{3}$, JOSÉ COELHO DE ARAÚJO FILHO ${ }^{4}$
}

\begin{abstract}
Nitisols are livelihood sources of agricultural and socio-economic development in several underdeveloped countries worldwide, including Brazil. Brazilian Nitisols are usually associated with basaltic rocks found in the Southern and Southeastern regions of the country. However, Nitisols derived from basalt also occur on the southern coast of Pernambuco state, a region under full urban, agricultural, and industrial development. Aiming to understand the relationship between climate and attributes of Nitisols from the southern coast of Pernambuco, we performed morphological descriptions, physical and chemical analyzes, iron selective extraction, and soil mineralogy (sand, silt, and clay) for three basaltic soil profiles along a land slope. The results suggest a strong weathering of the profiles due to climate conditions, besides a great loss of basic cations and xanthization process, resulting in the natural genesis of acric Nitisols with yellowish coloration, which has not been yet cataloged for this soil order in the Brazilian taxonomic system. In addition, there is a variation for physical attributes of Nitisols along the slope.
\end{abstract}

Keywords: Tropical soils. Soil-environment relationship. Xanthization process.

\section{ASSOCIAÇÕES ENTRE OS ATRIBUTOS DE NITOSSOLOS E O CLIMA DA COSTA SUL DE PERNAMBUCO}

RESUMO - Os Nitossolos dão suporte ao desenvolvimento agrícola e socioeconômico de muitos países subdesenvolvidos do mundo, incluindo o Brasil. Os Nitossolos brasileiros estão geralmente associados às rochas basálticas das regiões Sul e Sudeste. Entretanto, Nitossolos derivado de basalto também ocorrem na costa sul de Pernambuco, uma região em pleno desenvolvimento urbano, agrícola e industrial. Objetivando compreender as relações entre o clima e os atributos dos Nitossolos da costa sul de Pernambuco, foram realizadas descrições morfológicas, análises físicas e químicas, extrações seletivas de ferro e a determinação da mineralogia das frações areia, silte e argila de três perfis derivados de basalto ao longo de uma vertente. Os resultados demonstram que o clima da região implica em forte intemperização dos perfis, em grande perda de bases e favorece o processo de xantização, resultando na singular gênese de Nitossolos com matizes amarelados e caráter ácrico, fato que até o momento ainda não foi catalogado para esta ordem no sistema taxonômico brasileiro. Os resultados também demonstram a variação dos atributos físicos dos Nitossolos ao longo da vertente.

Palavras-chave: Solos tropicais. Relação solo-ambiente. Processo de xantização. 


\section{INTRODUCTION}

Soils under tropical climates provide support to much of the agricultural production of underdeveloped countries, supplying the worldwide rising demand for food (LEPSCH, 2011). Nitisols take part in this global scenario because they cover large areas in developing regions of the African continent, Southwestern Asia, Australia, and South America (FAO, 2006).

Nitisols described in Kenya (QURESHI; NJIHIA, 1984) and in Australia (CSIRO, 1989) show a positive charge balance and an acric character. An acric character evidences an advanced soil weathering, indicating high loss of exchangeable bases and increase of positive charges from the formation of $\mathrm{Fe}$ and $\mathrm{Al}$ oxides and hydroxides in the clay fraction (LEPSCH, 2011). Notwithstanding, the Brazilian System of Soil Classification (SiBCS) admits the acric character only for Latossolos (Ferralsols) (FAO, 2006; SANTOS et al., 2013).

In Brazil, Nitisols are associated with basaltic rocks from Paraná basin (CANER et al., 2014). Altered basaltic rocks, which are rich in ferromagnesian minerals, generally give rise to Red Nitisols with a negative net charge and absence of acric character (COOPER; VIDAL-TORRADO, 2005). These types of soils are usually found in the Southern and Southeastern regions of the country, under a hot weather with dry winters. Sugarcane industry is the sector that most uses these soils, followed by citrus, coffee, and other agricultural commodities of importance to the global market (LEPSCH, 2011).

In the northeast of Brazil, in the Southern coast of Pernambuco state, Nitisol formation is associated with basaltic rocks from the volcano-sedimentary basin of Cabo, under hot and constantly humid climate. Despite the high iron input from basalt weathering, some of these Nitisols show a yellowish hue, due to, among other factors, a better soil moisture maintenance (OLIVEIRA; FERREIRA; MARQUES, 2004). Soil water regime is also associated with the yellowish coloration of Nitisols with high levels of $\mathrm{Fe}$, as described in Kenya (QURESHI; NJIHIA, 1984) and in Australia (CSIRO, 1989).

The study region presents a major urban, agricultural, and industrial development owning to the sugarcane agro-industry growth and the port complex of Suape (NASCIMENTO et al., 2008). Among the few pedological studies developed in Cabo volcano-sedimentary basin, the one of Oliveira, Ferreira and Marques (2004) should be highlighted. In view of the above, further research on the soil-environment relationship are necessary for this region. Therefore, this study aimed to understand the relationship between attributes of three soil profiles of basalt-derived Nitisols, distributed along a slope, with the characteristic climate of the southern coast of Pernambuco state (Brazil).

\section{MATERIAL AND METHODS}

The study area is located on the southern coast of Pernambuco state in northeastern Brazil (Figure 1). The area is located within a region that geologically comprises the basaltic rocks of the volcano-sedimentary basin of Cabo (NASCIMENTO et al., 2008). A megathermal tropical climate (As') prevails in the region (KÖPPEN, 1931), with maximum temperatures close to $31{ }^{\circ} \mathrm{C}$ and average annual rainfall of $2050 \mathrm{~mm}$ (DA SILVA; QUELUZ; KLAR, 2013).

Three profiles were selected in a basalt slope, being described and sampled following Santos et al. (2015), and classified according to the SiBCS and WRB (FAO, 2006; SANTOS et al., 2013). Profile 1 $(\mathrm{P} 1), 2$ (P2), and $3(\mathrm{P} 3)$ are respectively located in the upper $\left(08^{\circ} 32^{\prime} 32.9^{\prime \prime} \mathrm{S}\right.$ and $\left.35^{\circ} 04^{\prime} 45.3^{\prime \prime} \mathrm{W}\right)$, middle $\left(08^{\circ} 32^{\prime} 32.9^{\prime \prime} \mathrm{S}\right.$ and $\left.35^{\circ} 04^{\prime} 47.7^{\prime \prime} \mathrm{W}\right)$ and lower $\left(08^{\circ} 32^{\prime} 33.0^{\prime \prime} \mathrm{S}\right.$ and $\left.35^{\circ} 04^{\prime} 49.0^{\prime \prime} \mathrm{W}\right)$ thirds of the slopes, at altitudes of 51, 32, and 27 meters, respectively. The area has been grown with sugarcane, being surrounded by sub-evergreen native forest remnants. The local relief is wavy within the domain of "seas of hills" (NASCIMENTO et al., 2008).

Physical and chemical analyzes were performed from fine earth fraction samples according to Donagema et al. (2011), including: (1) grain size, (2) particle density, (3) soil density, (4) total organic carbon (TOC), (5) $\mathrm{pH}$ in water and in $1 \mathrm{~mol} \mathrm{~L}^{-1} \mathrm{KCl}$ (1: 2.5 ratio), and (6) exchangeable $\mathrm{Ca}^{+2}, \mathrm{Mg}^{+2}, \mathrm{Al}^{+3}, \mathrm{Na}^{+}$, and $\mathrm{K}^{+}$. From these analysis data, we could estimate the degree of flocculation (DF), DpH, sum of bases (S), cation exchange capacity (CEC), and aluminum saturation (m).

Iron contents extracted by ammonium oxalate $\left(\mathrm{Fe}_{\mathrm{o}}\right)$, by sodium dithionite-citrate-bicarbonate $\left(\mathrm{Fe}_{\mathrm{d}}\right)$, and by $\mathrm{H}_{2} \mathrm{SO}_{4}$ via sulfuric attack $\left(\mathrm{Fe}_{\mathrm{t}}\right)$ were determined. Afterwards, we calculated the ratios $\mathrm{Fe}_{\mathrm{o}} /$ $\mathrm{Fe}_{\mathrm{d}}$ and $\mathrm{Fe}_{\mathrm{d}} / \mathrm{Fe}_{\mathrm{t}}$ (CORNELL; SCHWERTMANN, 2003). From the $\mathrm{SiO}_{2}, \mathrm{Al}_{2} \mathrm{O}_{3}$, and $\mathrm{Fe}_{2} \mathrm{O}_{3}$ contents, obtained by sulfuric attack, $\mathrm{Ki}$ and $\mathrm{Kr}$ values were calculated. All elements were determined by means of atomic absorption spectrometry. 


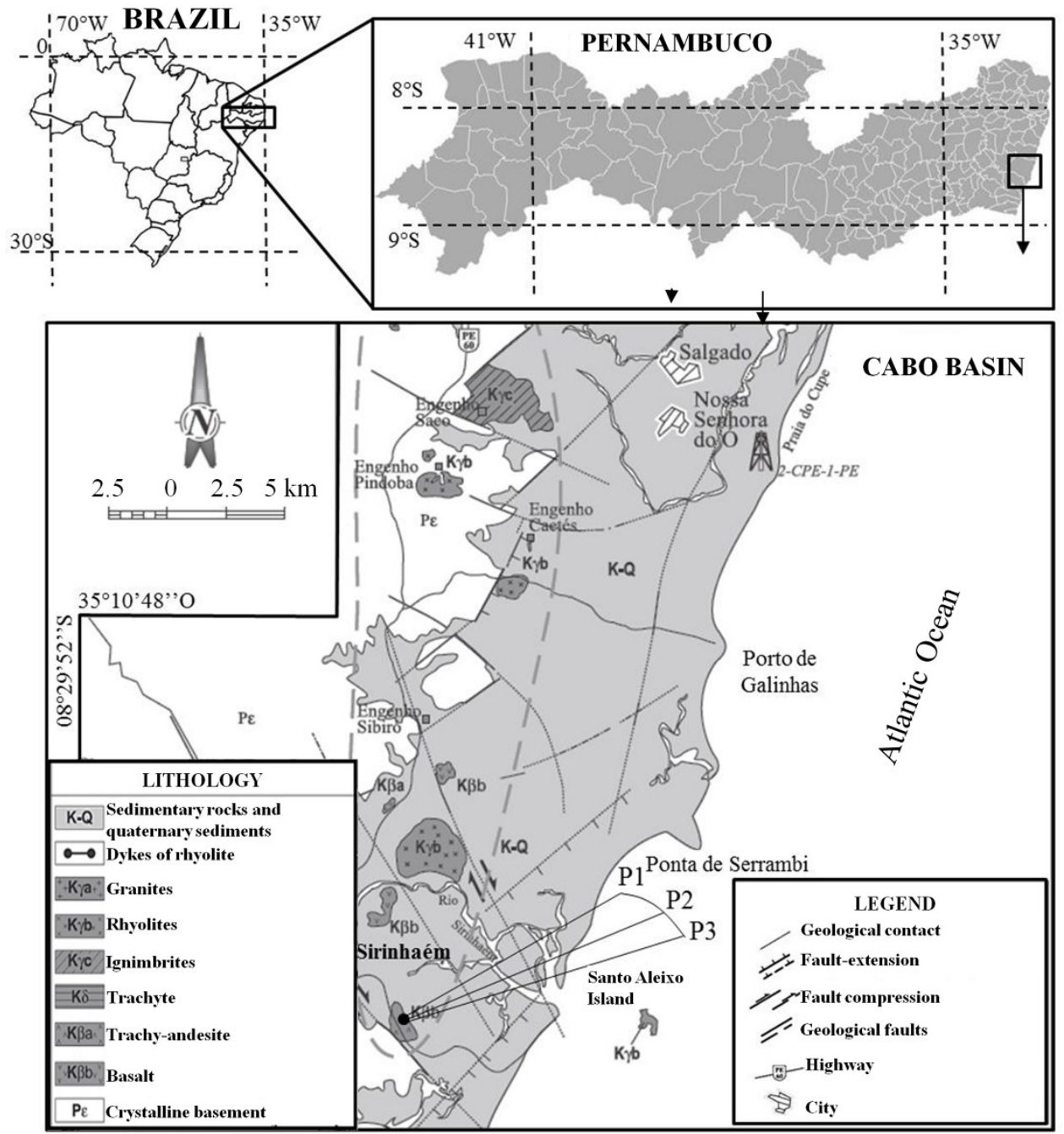

Figure 1. Location of the profiles in the volcano-sedimentary basin of Cabo. Modified from Lima Filho (1998).

Crystalline iron oxides were concentrated and determined in the clay fraction (SINGH; GILKES, 1991). The Gt/ Gt+Hm ratio was determined from oxide-concentrated samples. For clay minerals, the obtained clay fraction was treated to remove organic matter and oxides. Saturation treatments were applied with $\mathrm{MgCl}_{2}$ and $\mathrm{KCl}$ solutions, with readings at room temperature and after heating at $550{ }^{\circ} \mathrm{C}$. For that, oriented aggregate and non-oriented powder samples were prepared on glass slides.

Clay and silt fractions were analyzed by X-ray diffraction (Shimadzu XRD-6000). For oriented-aggregate samples, the scanning range was from 2 to $35^{\circ} 2 \Theta$, at a speed of $0.5^{\circ} 2 \Theta \mathrm{min}^{-1}$. While for non-oriented powder samples, the range varied between 3 and $70^{\circ} 2 \Theta$, at $1^{\circ} 2 \Theta \mathrm{min}^{-1}$. For both, a current of $20 \mathrm{~mA}$ was used, as well as a graphite monochromatized $\mathrm{CuK} \alpha$ radiation at $40 \mathrm{kV}$.

Database and criteria of Brown and Brinddley (1980) and Moore and Reynolds (1989) were used for interpreting the diffractograms. The dominance of oxides was inferred by the relationship between the reflection intensities of the planes goethite (110) and hematite (102).

Differential thermal and thermogravimetry analyses (DTA-TG) were performed simultaneously within a temperature range of 35 to $1,100{ }^{\circ} \mathrm{C}$, with a heating rate of $10{ }^{\circ} \mathrm{C}$ min-1, under $\mathrm{N}_{2}$ atmosphere. Data were computed using Proteus software v 5.1 (Netzsch). Gibbsite and kaolinite amounts were determined according to Karathanasis (2008).

\section{RESULTS AND DISCUSSION}

The climate in Pernambuco's south coast promoted the formation of well-structured and pedogenetically-developed soils with yellowish hues, being the three profiles classified as Nitossolos Háplicos Acriférricos típicos (SANTOS et al., 2013) or Nitisols (FAO, 2006) with very clayey texture, under a sub-evergreen tropical forest stage, on a gently wavy relief (Figure 2). 


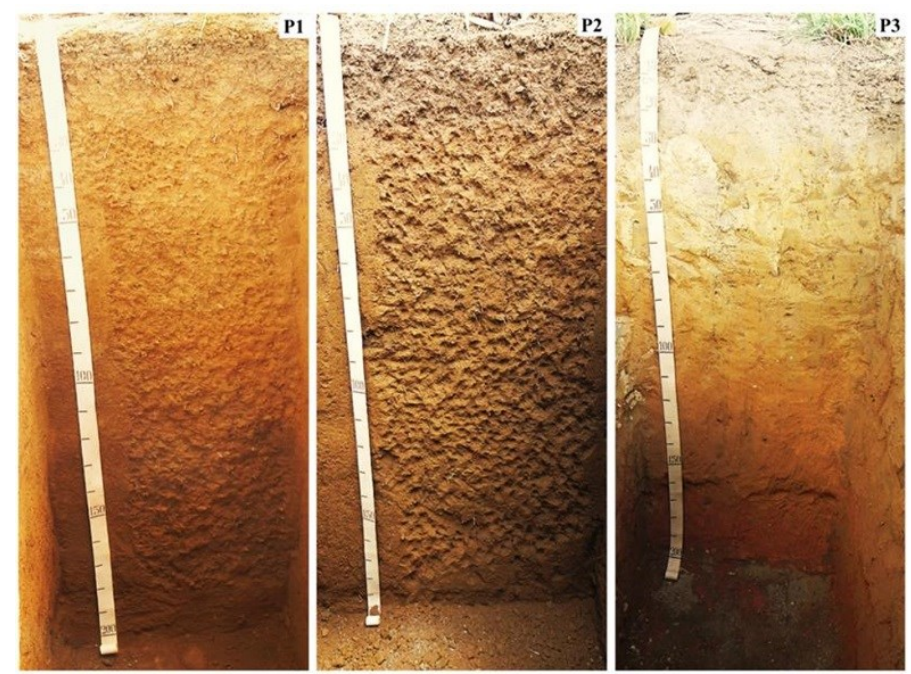

Figure 2. Image of the three profiles described in the south coast of Pernambuco.

The soil position within the slope had no strong influence on its morphological attributes. Such uniformity can be attributed to a wide susceptibility of basalt saprolite to constantly hot and humid climates, as in the region, resulting in a uniform development regardless of the land position.
The high degree of weathering of the soil profiles led to clayey textures and structuring degree from moderate to strong in the surface horizons. $\mathrm{Bt}$ horizons have highly clayey textures and moderate cerosity, evidencing an increasing clay fraction in the subsurface (Table 1).

Table 1. Morphological attributes of the three profiles.

\begin{tabular}{|c|c|c|c|c|c|c|c|}
\hline \multirow{2}{*}{ Horizon } & \multirow{2}{*}{$\begin{array}{l}\text { Depth } \\
\text { (m) }\end{array}$} & \multirow{2}{*}{ Texture } & \multirow{2}{*}{ Color } & \multirow{2}{*}{ Cerosity } & \multicolumn{3}{|c|}{ Structure } \\
\hline & & & & & Grade & Size & Shape \\
\hline \multicolumn{8}{|c|}{ P1 (Upper third) } \\
\hline Ap & $0-0.2$ & Clay & $7.5 Y R 3 / 3$ & Absent & Mod & Sm; Med & Gr e Bl Sub \\
\hline BA & $0.2-0.5$ & Vr clayey & 7.5YR 4/4 & Mod; Abun & Mod & Vr Sm; Sm & B1 Sub; Ang \\
\hline Bt1 & $0.5-0.9$ & Vr clayey & $7.5 \mathrm{YR} 4 / 4$ & Mod; Abun & Mod & Vr Sm; Sm & B1 Sub; Ang \\
\hline Bt2 & $0.9-1.6$ & Vr clayey & 7.5YR 4/6 & Mod; Abun & Mod & Sm; Med & B1 Sub; Ang \\
\hline Bt3 & $1.6-2.0+$ & Vr clayey & 7.5YR 4/6 & Mod; Abun & Mod & Sm; Med & B1 Sub; Ang \\
\hline \multicolumn{8}{|c|}{ P2 (Middle third) } \\
\hline Ap & $0-0.2$ & Clay & $10 Y R 3 / 4$ & Absent & Mod & Vr Sm; Sm & Gr; Bl Sub \\
\hline BA & $0.2-0.5$ & Vr clayey & $10 Y R 4 / 4$ & Mod; Abun & Mod & Vr Sm; Sm & B1 Sub; Ang \\
\hline Bt1 & $0.5-1.0$ & Vr clayey & $10 \mathrm{YR} 4 / 4$ & Mod; Abun & Mod & Vr Sm; Sm & B1 Sub; Ang \\
\hline Bt2 & $1.0-1.7$ & Vr clayey & $10 \mathrm{YR} 4 / 4$ & Mod; Com & Mod & Vr Sm; Sm & Bl Sub \\
\hline Bt3 & $1.7-2.0+$ & Vr clayey & $10 Y R 4 / 4$ & Mod; Com & Mod & Vr Sm; Sm & Bl Sub \\
\hline \multicolumn{8}{|c|}{ P3 (Lower third) } \\
\hline Ap & $0-0.1$ & Clay & $10 Y R 3 / 3$ & Absent & Mod & Vr Sm; Sm & Gr \\
\hline $\mathrm{AB}$ & $0.1-0.2$ & Vr clayey & $10 \mathrm{YR} 4 / 4$ & Mod; Abun & Mod & Sm; Med & B1 Sub \\
\hline BA & $0.2-0.4$ & Vr clayey & $10 \mathrm{YR} 4 / 4$ & Mod; Abun & Mod & Sm; Med & B1 Sub; Ang \\
\hline Bt1 & $0.4-0.9$ & Vr clayey & $10 \mathrm{YR} 4 / 4$ & Mod; Abun & Mod & Sm; Med & B1 Sub \\
\hline Bt2 & $0.9-1.5$ & Vr clayey & $10 \mathrm{YR} 4 / 4$ & Mod; Abun & Mod & Sm; Med & Bl Sub \\
\hline $\mathrm{Bt} 3$ & $1.5-2.0^{+}$ & Vr clayey & $10 \mathrm{YR} 4 / 4$ & Mod; Com & Mod & Sm; Med & Bl Sub \\
\hline
\end{tabular}

Mod = moderate; Abun = abundant; Com = common; $\mathrm{Sl}=$ small; Med = medium; $\mathrm{Gr}=$ granular; $\mathrm{Bl}=$ blocky;

$\mathrm{Sub}=$ subangular; Ang $=$ angular. 
The original basalt mineralogy, rich in ferromagnesian minerals (CAMPOS et al., 2012), raised particle density values (Table 2); however, soil density was lower than $1.4 \mathrm{~g} \mathrm{~cm}^{-3}$ (Table 2). It can be associated with some factor such as sandfraction low content, clay-content prevalence (Table 2), secondary mineralogy, and high the microporosity of these soils (CANER et al., 2014). The soil density values found here are lower than are those reported by Oliveira, Ferreira and Marques (2004) for soils in this region. These smaller values should be associated with a minor contribution of tertiary sandy quartz sediments and eolic sediments in the Nitisols studied here.

Table 2. Physical and chemical attributes of the three profiles.

\begin{tabular}{|c|c|c|c|c|c|c|c|c|c|c|c|c|c|c|}
\hline \multirow{3}{*}{ Hor } & \multicolumn{3}{|c|}{ Granulometry } & \multirow{3}{*}{$\begin{array}{c}\text { DF } \\
\%\end{array}$} & \multicolumn{2}{|c|}{ Density } & \multicolumn{2}{|c|}{$\mathrm{pH}$} & \multirow{3}{*}{$\Delta \mathrm{pH}$} & \multirow{2}{*}{$\mathrm{S}$} & \multirow{2}{*}{$\mathrm{Al}^{3+}$} & \multirow{2}{*}{ CEC } & \multirow{2}{*}{$\mathrm{m}$} & \multirow{2}{*}{ TOC } \\
\hline & Sand & Silt & Clay & & Soil & particle & \multirow{2}{*}{$\mathrm{H}_{2} \mathrm{O}$} & \multirow{2}{*}{$\mathrm{KCl}$} & & & & & & \\
\hline & \multicolumn{3}{|c|}{$\left(\mathrm{g} \mathrm{kg}^{-1}\right)$} & & \multicolumn{2}{|c|}{$\left(\mathrm{g} \mathrm{cm}^{-3}\right)$} & & & & \multicolumn{3}{|c|}{$\left(\mathrm{cmol}_{\mathrm{c}} \mathrm{kg}^{-1}\right)$} & $\%$ & $\mathrm{~g} \mathrm{~kg}^{-1}$ \\
\hline \multicolumn{15}{|c|}{ P1 (Upper third) } \\
\hline Ap & 305 & 198 & 497 & 18 & 1.40 & 2.82 & 5.6 & 5.0 & -0.6 & 0.6 & 0.05 & 6.2 & 8 & 12.5 \\
\hline $\mathrm{BA}$ & 168 & 210 & 622 & 79 & 1.17 & 2.86 & 5.6 & 5.5 & -0.1 & 0.2 & 0.05 & 3.9 & 20 & 9.7 \\
\hline Bt1 & 199 & 175 & 626 & 79 & 1.22 & 2.85 & 5.4 & 5.5 & 0.1 & 0.2 & 0.05 & 3.9 & 20 & 7.0 \\
\hline $\mathrm{Bt} 2$ & 186 & 139 & 675 & 81 & 1.21 & 2.81 & 5.3 & 5.4 & 0.1 & 0.2 & 0.05 & 3.5 & 23 & 5.8 \\
\hline Bt3 & 139 & 212 & 649 & 81 & 1.18 & 2.91 & 5.3 & 5.3 & 0.0 & 0.2 & 0.05 & 4.1 & 23 & 4.5 \\
\hline \multicolumn{15}{|c|}{ P2 (Middle third) } \\
\hline Ap & 177 & 245 & 578 & 31 & 1.12 & 2.93 & 4.8 & 4.3 & -0.5 & 0.4 & 0.3 & 9.2 & 41 & 21.5 \\
\hline $\mathrm{BA}$ & 116 & 280 & 604 & 79 & 1.13 & 2.95 & 5.2 & 5.2 & 0.0 & 0.2 & 0.1 & 4.4 & 35 & 9.9 \\
\hline Bt1 & 129 & 223 & 648 & 81 & 1.07 & 2.93 & 5.2 & 5.4 & 0.2 & 0.2 & 0.05 & 3.5 & 24 & 7.1 \\
\hline $\mathrm{Bt} 2$ & 129 & 231 & 640 & 81 & 1.13 & 2.95 & 5.3 & 5.6 & 0.3 & 0.2 & 0.05 & 3.6 & 20 & 6.3 \\
\hline $\mathrm{Bt} 3$ & 310 & 62 & 628 & 81 & 1.12 & 2.87 & 4.9 & 5.0 & 0.1 & 0.1 & 0.1 & 4.0 & 63 & 6.2 \\
\hline \multicolumn{15}{|c|}{ P3 (Lower third) } \\
\hline Ap & 119 & 303 & 578 & 39 & 1.05 & 2.74 & 5.7 & 5.1 & -0.6 & 1.1 & 0.15 & 8.6 & 12 & 30.3 \\
\hline $\mathrm{AB}$ & 106 & 261 & 633 & 79 & 1.17 & 2.81 & 5.0 & 4.6 & -0.4 & 0.5 & 0.15 & 7.9 & 24 & 22.7 \\
\hline BA & 78 & 304 & 618 & 79 & 1.16 & 2.80 & 5.5 & 5.4 & -0.1 & 0.4 & 0.05 & 5.7 & 11 & 11.6 \\
\hline Bt1 & 78 & 273 & 649 & 81 & 1.03 & 2.86 & 5.2 & 5.3 & 0.1 & 0.3 & 0.05 & 5.2 & 13 & 8.8 \\
\hline $\mathrm{Bt} 2$ & 83 & 270 & 647 & 81 & 1.07 & 2.95 & 5.3 & 5.3 & 0.0 & 0.3 & 0.05 & 6.0 & 14 & 6.5 \\
\hline $\mathrm{Bt} 3$ & 82 & 271 & 647 & 81 & 1.16 & 2.93 & 5.0 & 4.6 & -0.4 & 0.1 & 0.35 & 6.7 & 81 & 5.6 \\
\hline
\end{tabular}

Hor $=$ horizon; $\mathrm{DF}=$ degree of flocculation; $\mathrm{S}=$ sum of bases; $\mathrm{CEC}=$ cation exchange capacity; $\mathrm{m}=\mathrm{Al}$ saturation; $\mathrm{TOC}=$ total organic carbon.

The local wet climate and soil good drainage implied a great loss of exchangeable bases, being the base lower than $0.6 \mathrm{cmolc} \mathrm{kg}-1$ in all profiles (Table 2). CEC was also low, blow $27 \mathrm{cmol}_{\mathrm{c}} \mathrm{kg}^{-1}$ clay, and TOC decreased with soil depth (Table 2). Likewise, Sobrinho, Almeida and Erhart (2009) observed low values of base sum and CEC in soils derived from basalt in the highlands of Eastern Santa Catarina state. There was a wide variation of $\mathrm{Al}$ saturation, from 8 to $81 \%$; however, exchangeable aluminum rates were low, varying from 0.05 to $0.35 \mathrm{cmol}_{\mathrm{c}} \mathrm{kg}^{-1}$ (Table 2).

Regarding $\mathrm{pH}$ in water, the studied Nitisols revealed moderately acidic reactions, ranging from 4.8 to 5.7 in surface horizons, and between 5.2 and 5.4 in Bt1 (Table 2). These findings are consistent with the kaolinite mineralogy of these soils, in which $\mathrm{H}^{+}$is the main acidity component, being dissociated from silanol and aluminol groups (WEBER et al., 2005).

As for $\mathrm{pH}$ in $\mathrm{KCl}$, values were superior to 5.0, making the $\Delta \mathrm{pH}$ become positive in the diagnostic horizons (Table 2), giving rise to a positive charge balance to the soil. Furthermore, the sum of exchangeable bases plus KCl-extractable aluminum was less than $1.5 \mathrm{cmol}_{\mathrm{c}} \mathrm{kg}^{-1}$. These chemical characteristics constitute the acric character (SANTOS et al., 2013).

Although the acric character has already been described in Nitisols of Kenya (QURESHI; NJIHIA, 1984) and Australia (CSIRO, 1989). The SiBCS have not reported it yet (SANTOS et al., 2013). 
Hence, our findings led us to suggest future studies for classification purposes in the region, mainly targeting at including the acric trait in Nitisols (Nitossolos) by the SiBCS.

Regular rainfalls throughout the entire year feature the climate encompassing the studied Nitisols. A constant rainfall on the southern coast of Pernambuco, associated with a good drainage, tend to raise the weathering rate of these Nitisols when compared to those described in the South and
Southeast of Brazil (DA SILVA; QUELUZ; KLAR, 2013).

The high loss of exchangeable bases (Table 2) and the positive charge balance from the large amounts of $\mathrm{Fe}$ and $\mathrm{Al}$ oxides and hydroxides in the clay fraction, e.g. hematite, goethite, and gibbsite (Table 3), are described as chemical conditions necessary for acric character expression in soils (LEPSCH, 2011).

Table 3. Mineralogy of the sand, silt and clay fractions of the three profiles obtained by XRD.

\begin{tabular}{cccccc}
\hline Profile & Sand & Silt & Clay $^{(1)}$ & Clay $^{(2)}$ & Clay $^{(3)}$ \\
\hline P1 (Upper third) & Qz, Fd & Qz,Fd, Mt, Kt, Gb, Gt & Kt, Gb, Gt, Hm & Kt & Gt, Hm \\
P2 (Middle third) & Qz, Fd & Qz, Fd, Mt, Kt, Gb, Gt & Kt, Gb, Gt, Hm & Kt & Gt, Hm \\
P3 (Lower third) & Qz, Fd & Qz, Fd, Mt, Kt, Gb, Gt & Kt, Gb, Gt, Hm & Kt & Gt, Hm \\
\hline
\end{tabular}

${ }^{(1)}=$ non-oriented clay; ${ }^{(2)}=$ oriented clay aggregates; ${ }^{(3)}=$ oxide concentrate; $\mathrm{Qz}=$ quartz; $\mathrm{Fd}=$ feldspar; $\mathrm{Mt}=$ magnetite

$\mathrm{Kt}=$ kaolinite; $\mathrm{Gb}=$ gibbsite; $\mathrm{Gt}$; goethite; $\mathrm{Hm}=$ Hematite .

Even though favorable conditions also occur in Nitisols from Paraná River basin (CANER et al., 2014); the peculiar climate of the southern coast of Pernambuco should make them more prominent, enhancing an acrid character in the volcano-sedimentary basin of Cabo. The positive $\Delta \mathrm{pH}$ in these soils could be attributed to gibbsite and crystalline iron oxides (DONAGEMMA et al., 2008). Goethite has a high PZC that exerts a strong influence on clay-fraction electrochemistry in some acric soils (CSIRO, 1989).

Soil structure and physical attributes of the three profiles had a potential impact on water dynamics through the surroundings. These environmentally interesting attributes make these soils resemble the Nitisols described in the Paraná River basin (COOPER; VIDAL-TORRADO, 2005), in Africa (QURESHI; NJIHIA, 1984), and those in Australia (CSIRO, 1989).

On the other hand, the studied Nitisols showed chemical and mineralogical attributes that are limiting to farming activities, mainly low CEC, and phosphorus fixation by iron oxides (Table 3). From an environmental point of view, the high point of zero charge (PZC) of iron oxides may contribute to sorption of heavy metals, which come from nearby agro-industry activities (CORNELL; SCHWERTMANN, 2003).

Local climate influence on the studied Nitisols can also be observed through their more yellowish hues (Table 1), which differ from the reddish hues of Nitisols from tropical climates with dry winter, as is the case of those developed from basaltic rocks in the Paraná River basin (GHINDIN et al., 2006). Even with hematite (Table 3) likely derived from drier paleoclimates, the yellow hues of the studied Nitisols are associated with goethite (Table 3), what reflects the current-climate influence, which is constantly moist, on conversion of hematite into goethite, the so-called xanthization. (OLIVEIRA; FERREIRA; MARQUES, 2004). The goethite dominance would be the result of hematite low stability under the current climatic condition of steady moisture (CORNELL; SCHWERTMANN, 2003).

Despite the morphological uniformity, soil profile position within the slope seems to alter silt and sand contents (Figure 3). Silt contents were higher in Ap horizons, which are at lower quotes (Figure 3A). This outcome was not observed in subsurface layers (Figure 3B), which shows a possible accumulation gradient along the transect, because of surface runoff of material from the ridge to the foothill.

A mineral absent in basalt rocks, quartz was present in the sand and silt fractions of the studied profiles (Table 3). It shows the contribution with sandy sedimentary materials from tertiary and with eolic sediments to the source material of the three soils (OLIVEIRA; FERREIRA; MARQUES, 2004). The decreasing contents of a sand fraction, in the surface (Figure 3A) and subsurface (Figure 3B) horizons, from the ridge to foothills might be related to a large contribution of Barreira's group with sedimentary material to the soil formation at the top of hills.

Unlike sand and silt, clay-fraction homogeneity among the three sections (Figure 3A and $\mathrm{B}$ ) is connected to the low propensity of kaolinite-oxide clays to lateral flows over the slope (COOPER; VIDAL-TORRADO, 2005).

One of the most important processes associated with weathering in these Nitisols has to do with the local climate effect on the partial loss of silica and its consequent secondary formation of kaolinite and iron oxides (Table 4). 
Horizons Ap

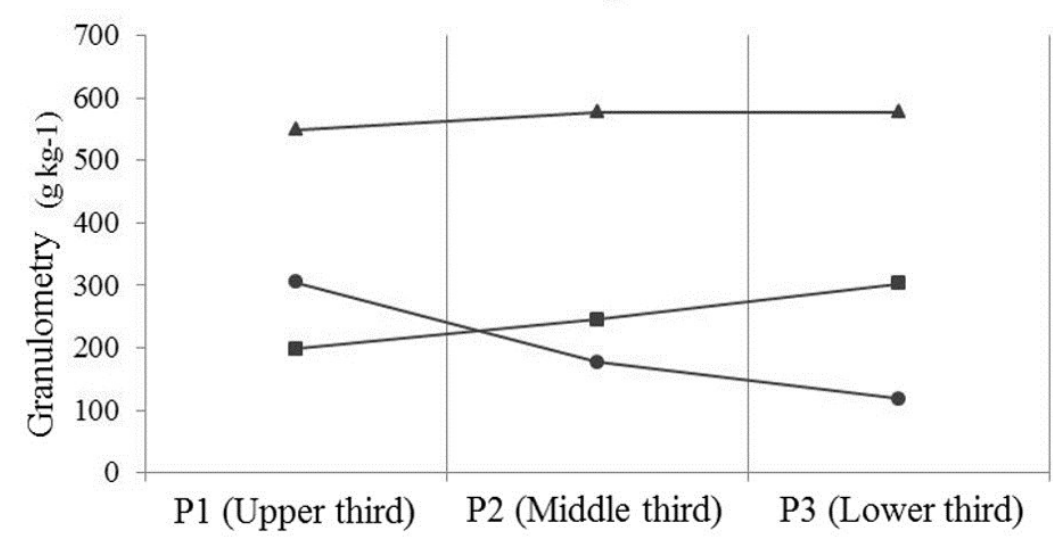

Horizons Bt2

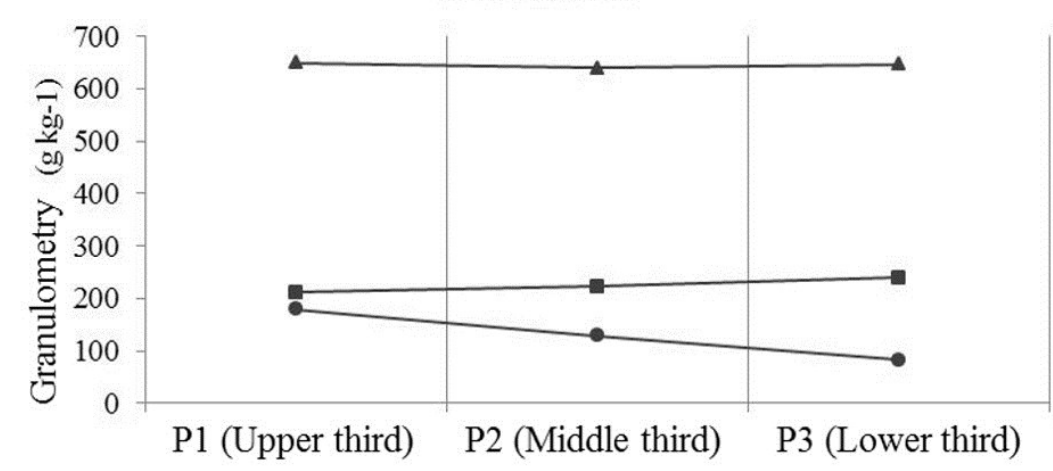

$\rightarrow$ Sand $\rightarrow$ Silt $\rightarrow$ Clay

Figure 3. Variation of the sand, silt and clay fractions in the surface and subsurface horizons of the three profiles from the upper third to the lower third of the slope. (A) Granulometric variation in horizons Ap. (B) Granulometric variation in Bt2 horizons.

Table 4. Fe-total $\left(\mathrm{Fe}_{\mathrm{t}}\right)$, Fe extracted by DCB $\left(\mathrm{Fe}_{\mathrm{d}}\right)$ and $\mathrm{OAA}\left(\mathrm{Fe}_{\mathrm{o}}\right), \mathrm{Fe}_{\mathrm{o}} / \mathrm{Fe}_{\mathrm{d}}, \mathrm{Fe}_{\mathrm{d}} / \mathrm{Fe}_{\mathrm{t}}$ ratios, $\mathrm{Gt} / \mathrm{Gt}+\mathrm{Hm}$ ratio and molecular relationships $\mathrm{Ki}$ and $\mathrm{Kr}$ in horizons of the three profiles.

\begin{tabular}{|c|c|c|c|c|c|c|c|c|c|c|}
\hline \multirow[t]{2}{*}{ Hor } & \multirow[t]{2}{*}{$\mathrm{Fe}_{\mathrm{d}}$} & $\mathrm{Fe}_{\mathrm{o}}$ & $\mathrm{Fe}_{\mathrm{t}}$ & \multirow{2}{*}{$\mathrm{Fe}_{\mathrm{o}} / \mathrm{Fe}_{\mathrm{d}}$} & \multirow{2}{*}{$\mathrm{Fe}_{\mathrm{d}} / \mathrm{Fe}_{\mathrm{t}}$} & \multirow{2}{*}{$(\mathrm{Gt} / \mathrm{Gt}+\mathrm{Hm})^{(1)}$} & \multirow{2}{*}{\multicolumn{2}{|c|}{$\begin{array}{c}\mathrm{Ct}^{(2)} \mathrm{Gb}^{(2)} \\
-\%- \\
\end{array}$}} & \multicolumn{2}{|c|}{$\begin{array}{l}\text { molecular } \\
\text { relationships }\end{array}$} \\
\hline & & \multicolumn{2}{|l|}{$\mathrm{g} \mathrm{kg}^{-1}$} & & & & & & $\mathrm{Ki}$ & $\mathrm{Kr}$ \\
\hline \multicolumn{11}{|c|}{ P1 (Upper third) } \\
\hline Ap & 127.60 & 2.35 & 170.13 & 0.02 & 0.75 & 0.62 & 88 & 3 & 1.3 & 0.8 \\
\hline Bt1 & 196.60 & 1.50 & 211.40 & 0.01 & 0.93 & 0.81 & 83 & $\mathrm{Nd}$ & 1.9 & 1.1 \\
\hline $\mathrm{Bt} 3$ & 182.82 & 1.09 & 192.44 & 0.01 & 0.95 & 0.76 & 76 & 6 & 1.7 & 1.1 \\
\hline \multicolumn{11}{|c|}{ P2 (Middle third) } \\
\hline Ap & 174.42 & 2.73 & 195.98 & 0.02 & 0.89 & 0.82 & 82 & 8 & 1.5 & 0.9 \\
\hline Bt1 & 203.18 & 1.67 & 207.33 & 0.01 & 0.98 & 0.81 & 82 & $\mathrm{Nd}$ & 1.6 & 1.0 \\
\hline $\mathrm{Bt} 3$ & 190.25 & 1.33 & 206.79 & 0.01 & 0.92 & 0.62 & 81 & 2 & 1.5 & 0.9 \\
\hline \multicolumn{11}{|c|}{ P3 (Lower third) } \\
\hline Ap & 169.35 & 2.34 & 206.52 & 0.01 & 0.82 & 0.77 & 87 & $\mathrm{Nd}$ & 1.8 & 1.0 \\
\hline Bt1 & 186.19 & 1.3 & 211.58 & 0.01 & 0.88 & 0.79 & 85 & $\mathrm{Nd}$ & 1.8 & 1.1 \\
\hline $\mathrm{Bt} 3$ & 172.87 & 1.36 & 254.22 & 0.01 & 0.68 & 0.80 & 84 & $\mathrm{Nd}$ & 1.6 & 0.9 \\
\hline
\end{tabular}

Hor $=$ horizon 
The dissolution of basalt ferromagnesian minerals under the current tropical humid climate contributed to an accumulation of oxides and iron oxyhydroxide in the assessed Nitisols (COOPER; VIDAL-TORRADO, 2005). In the studied soils, goethite stands out by quantity, being evidenced in the $\mathrm{Gt} / \mathrm{Gt}+\mathrm{Hm}$ ratio that varied from 0.62 to 0.81 (Table 4). Moreover, the contents of iron oxides and oxyhydroxide comply with the amount of iron extracted by DCB, reaching a value of $200 \mathrm{~g} \mathrm{~kg}^{-1}$ in the diagnostic horizons (Table 4).

Under good drainage conditions, local climate promotes partial hydrolysis of primary silicates, controlling the formation and stabilization of variable charge minerals (COSTA, 2012). This fact can be evidenced by the $\mathrm{Ki}$ and $\mathrm{Kr}$ indexes, 1.7 and 1.0, taking into account all the horizons of all the three profiles (Table 4). These values differentiate the current studied Nitisols from those studied in the geomorphological province of the Cuestas Basálticas, in the State of São Paulo (Brazil) (MEIRELES et al., 2012).

DTA-TG mineralogical analyses showed an unchanged kaolinite content regardless profile position (Table 4). Kaolinite formation is favored by the hot and humid local weather and by the source material rich in feldspar (NASCIMENTO et al., 2008), the main precursor for kaolinite (WEBER et al., 2005). The kaolinite contents found through DTA were similar to those described in soils derived from basalt in Southern and Southeastern Brazil (COOPER; VIDAL-TORRADO, 2005; GHINDIN et al., 2006).

The ratio $\mathrm{Fe}_{\mathrm{o}} / \mathrm{Fe}_{\mathrm{d}}$ reached values of 0.01 , confirming the dominance of iron crystalline phases (Table 4). The $\mathrm{Fe}_{\mathrm{o}}$ averages of $1.5 \mathrm{~g} \mathrm{~kg}^{-1}$ reveal that Fe low crystallinity and amorphous phases, in these soils, are lower than were those described in Nitisols studied by Alcântara and Camargo (2010) in Ribeirão Preto - SP (Brazil).

Nonetheless, the haplic Nitisols studied here show a great diversity of mineralogical, physical, and geochemical attributes, raising issues regarding their agricultural and environmental potentials.

\section{CONCLUSIONS}

The climate in Pernambuco south coast provides a pedogenic environment suitable to a high loss of silica under good drainage conditions, leading to the secondary formation of kaolinite and iron oxides under monosialitization and ferralitization processes.

The current climate, hot and humid, favors the formation of hydrated oxides as the goethite to the detriment of the hematite, resulting in a xanthization process and development of Nitisols with yellowish hues.

A positive $\Delta \mathrm{pH}, \mathrm{pH}$ in $\mathrm{KCl}$ superior to 5.0, and a low $\mathrm{Al}^{+3}$ content contributed to the acric trait in the studied Nitisols, which has so far not been cataloged for this order at the Brazilian soil taxonomic system, and which also make them resemble the Nitisols described in Africa and Australia.

\section{REFERENCES}

ALCÂNTARA, M. A. K.; CAMARGO, O. A Movimentação de nitrato em horizonte superficial e subsuperficial de Latossolo e Nitossolo com cargas variáveis. Pesquisa Agropecuária Brasileira, Brasília, v. 45, n. 1, p. 81-88, 2010

BROWN, G.; BRINDLEY, G. W. X-ray Diffraction Procedures for clay mineral Identification In: BRINDLEY， G. W.; BROWN， G. X-ray identification and crystal structures of clay minerals. 2. ed. London: Mineralogical Society, 1980. cap. 11 , p. 305-360.

CAMPOS, M. C. et al. Discrimination of geomorphic surfaces with multivariate analysis of soil attributes in sandstone - basalt lithosequence. Revista Ciência Agronômica, Fortaleza, v. 43, n. 3, p. 429-438, 2012.

CANER, L. et al. Basalt and rhyo-dacite weathering and soil clay formation under subtropical climate in southern Brazil. Geoderma, Amsterdam, v. 62, n. 1, p. $100-112,2014$.

COOPER, M.; VIDAL-TORRADO, P Caracterização morfológica, micromorfológica e físico-hídrica de solos com horizonte $\mathrm{B}$ Nítico. Revista Brasileira de Ciências do Solo, Viçosa, v. 29 , n. 1, p. $581-595,2005$.

CORNELL, R. M.; SCHWERTMANN, U. The Iron Oxides: Structure, Properties, Reactions, Occurences and Uses. 3. ed. Weinheim: Verlang Gmbh \& Co. KGaA, 2003. 462 p.

COSTA, E. U. C. Caracterização e gênese de Argissolos e Nitossolos na Bacia Cabo, Pernambuco. 2012. 128 f. Dissertação (Mestrado em Ciência do Solo: Área de Concentração em Gênese e mineralogia do solo) - Universidade Federal Rural de Pernambuco, Recife, 2012.

CSIRO. Soil Landscape relations in basaltic soils at innisfail. 3. ed. North Quensland: Wotler, 1989. $23 \mathrm{p}$

DA SILVA, A. O.; QUELUZ, J. T. G.; KLAR, A. E. Spatial distribution of climatic water balance in different rainfall regimes in the State of Pernambuco. Brazilian Journal of Applied Technology for 
Agricultural Science, Guarapuava, v. 6, n. 1, p. 719, 2013.

DONAGEMA, G. K. et al. Manual de métodos e análises de solos. 3. ed. Rio de Janeiro, RJ: Embrapa Solos, 2011. 212 p.

DONAGEMMA, G. K. et al. Fósforo remanescente em argila e silte retirados de latossolos após prétratamentos na análise textural. Revista Brasileira de Ciência do Solo, Viçosa, v. 32, n. 2, p. 1785 1791, 2008.

FOOD AND AGRICULTURE ORGANIZATION FAO. World reference base for soil resources. A framework for international classification, correlation and communication, World. 2. ed. Roma: Lazio, 2006. 145 p.

GHINDIN, A. A. et al. Topossequência de Latossolos originados de rochas basálticas no Paraná. II - Relação entre mineralogia da fração argila e propriedades físicas dos solos. Revista Brasileira de Ciência do Solo, Viçosa, v. 30, n. 2, p. 307-319, 2006.

KARATHANASIS, A. D. Thermal analysis of soil minerals. In: ULERY, A. L.; DREES, R. (Eds.). Methods of Soil Analysis - Mineralogical Methods. Madison: Soil Science Society of America, 2008, v. 2, cap. 5, p. 117-160.

KÖPPEN, W. P. Grundriss der Klimakunde. 2. ed. Berlin: Walter de Gruyter, 1931. 388 p.

LEPSCH, I. F. Intemperismo dos minerais e formação dos minerais de argila. In: LEPSCHI, I. F. (Ed.). 19 lições de pedologia. São Paulo: Oficina de textos, 2011. cap. 3, p. 66-82.

LIMA FILHO, M. F. Análise estratigráfica e estrutural da Bacia Pernambuco. 1998. $139 \mathrm{f}$. Tese. (Doutorado em geologia: Área de Concentração em Geoquímica e Geotectônica) Universidade de São Paulo, São Paulo, 1998.

MEIRELES, H. T. et al. Relações solo-paisagem em topossequência de origem basáltica. Pesquisa Agropecuária Tropical, Goiânia. Revista Brasileira de Ciência do Solo, Viçosa, v. 42, n. 2, p. 129-136, 2012.

MOORE, D. M.; REYNOLDS, R. C. X-ray diffraction and identification and analysis of clay minerals. 2. ed. Oxford: Oxford University Press, 1989. $332 \mathrm{p}$.

NASCIMENTO, M. A. L. et al. Ignimbritos do Engenho Saco, Ipojuca, PE. In: SOUZA, Z. S. et al.
(Eds.). Registro de vulcanismo explosivo cretáceo na Província Magmática do Cabo. Recife: SIGEP, 2008. v. 3, cap. 3, p. 237-250.

OLIVEIRA, L. B. O.; FERREIRA, M. G. V. X.; MARQUES, F. A. Characterization and classification of two Soils derived from basic rocks in Pernambuco State coast, northeast Brazil. Scientia Agricola, Piracicaba, v. 61, n. 6, p. 615-25, 2004.

QURESHI, J. N.; NJIHIA C. M. Soil related constraints to crop production in east Africa. 1. ed. Nyeri: Isric Library, 1984, 217 p.

SANTOS, H. G. et al. Sistema brasileiro de classificação de solos. 3. ed. Brasília, DF: Empresa Brasileira de Pesquisa Agropecuária, 2013. 353 p.

SANTOS, R. D. et al. Manual de descrição e coleta de solo no campo. 2. ed. Viçosa, MG: Sociedade Brasileira de Ciência do Solo, 2015.85 p.

SINGH, B.; GILKES, R. J. Concentration of oxides from soil clays by $\mathrm{M} \mathrm{NaOH}$ treatment: the complete removal of sodalite and kaolin. Clay Minerals. Amsterdam, v. 26, n. 1, p. 463-472, 1991.

SOBRINHO, J. B. P; ALMEIDA, J. A.; ERHART, J. Mineralogia, propriedades químicas e classificação de solos das Serras do Leste Catarinense. Revista de Ciências Agroveterinárias, Lages, v. 8, n. 1, p. 924, 2009.

WEBER, O. L. S. et al. Cargas elétricas estruturais e variáveis de Solos tropicais altamente intemperizados. Revista Brasileira de Ciência do Solo, Viçosa, v. 29, n. 3, p. 867-873, 2005. 